\title{
HUBUNGAN KARAKTERISTIK IBU DENGAN PEMBERIAN ASI EKSKLUSIF
}

\section{Correlation of Mother's Characteristic with Exclusive Breastfeeding}

\author{
Abd. Hakim \\ Badan Pusat Statistik Provinsi Aceh, Jl. TGK. HM. Daud Beureueh No. 50 Banda Aceh 23121
}

Koresponding Penulis: ahakim@bps.go.id

Abstrak

Pembangunan Sumber Daya Manusia merupakan suatu yang sangat penting dan harus mendapat perhatian serius sejak dini. Anak yang baru lahir perlu dipersiapkan agar tumbuh sehat dan cerdas, karena mereka aset bangsa yang memegang peranan di masa depan. Program pemberian ASI Eksklusif menjadi penting. PP No. 33 Tahun 2012 tentang Pemberian ASI Eksklusif, sebagai bukti bahwa Pemerintah menaruh perhatian yang tinggi. Agar program tersebut berhasil dengan baik perlu dukungan berbagai pihak. Sementara itu, berdasarkan data BPS pada tahun 2018, bayi berusia kurang dari enam bulan yang mendapat ASI Eksklusif di Provinsi Aceh relatif sedikit yaitu 33,33 persen. Penelitian ini bertujuan untuk mengidentifikasi dan mengkaji karakteristik ibu menyusui dan variabel yang berhubungan dengan pemberian ASI Eksklusif. Data yang digunakan adalah data hasil Survei Sosial Ekonomi Nasional (Susenas) Provinsi Aceh tahun 2019. Empat variabel dipilih dan diuji menggunakan alat uji statistik chi square dengan tingkat signifikan 5\%. Berdasarkan hasil uji chi square, variabel yang berhubungan secara nyata dengan pemberian ASI Eksklusif adalah tingkat pendidikan, status bekerja, dan tempat melahirkan. Sedangkan umur ibu tidak terdapat hubungan yang nyata dengan pemberian ASI Eksklusif.

Kata Kunci: ASI Eksklusif, Karakteristik Ibu, Tempat melahirkan.

Abstract

Human Resources Development is a very important and must serious attention early on. Newborn babies need to be prepared to grow up healthy and smart, because they are the nation's assets for the future. Exclusive breastfeeding programs are important. PP No. 33 in 2012 about Exclusive Breastfeeding, as proof that the Government is high attention. For the program succeed, it needs the support of various parties. Meanwhile, based on BPS data in 2018, infants aged less than six months who received exclusive breastfeeding in Aceh Province were relatively small at 33.33 percent. This study aims to identify the characteristics of breastfeeding mothers and the variables related with exclusive breastfeeding. The data used are the results National Province Social Economic Survey (Susenas) of Aceh Province in 2019. Four variables were selected and tested using a chi square statistical test with a significant level of 5\%. Based on the results of the chi square test, the variables significantly related to exclusive breastfeeding are the level of education, work status, and place of birth. While the age of the mother is not significantly related to exclusive breastfeeding.

Keywords: Exclusive Breastfeeding, characteristics of mother, place of birth.

\section{PENDAHULUAN}


Kesehatan dan kecerdasan merupakan salah satu faktor penting dalam membangun kualitas sumber daya manusia (SDM). Dengan kesehatan dan kecerdasan seseorang akan lebih produktif dan mampu meningkatkan daya saing, sehingga dapat menjadi SDM yang unggul. Pembangunan dan pembentukan SDM yang sehat dan cerdas harus mendapat perhatian serius sejak dini. Anak sejak pertama kali lahir perlu dipersiapkan agar tumbuh sehat dan cerdas. Mereka merupakan aset bangsa yang bernilai tinggi, karena akan memegang peranan di masa depan. Pemberian Air Susu Ibu (ASI) Eksklusif pada bayi merupakan salah satu cara terbaik untuk meningkatkan kualitas SDM sejak dini, karena sudah menjadi rahasia umum dan tidak dapat dipungkiri bahwa ASI merupakan asupan makanan terbaik untuk bayi.

World Health Organization/WHO (2020) dalam publikasinya berjudul "Breastfeeding and COVID-19" menyatakan bahwa menyusui merupakan landasan utama untuk kelangsungan hidup, kecukupan nutrisi, dan perkembangan bagi bayi/balita, serta kesehatan ibu. WHO merekomendasikan pemberian ASI Eksklusif selama 6 bulan pertama kehidupan, dilanjutkan dengan makanan pendamping hingga 2 tahun atau lebih. Kontak awal antara kulit ibu dengan bayi juga dapat meningkatkan kelangsungan hidup neonatal dan mengurangi morbiditas. Agar rekomendasi tersebut dapat terlaksana dengan baik, harus didukung dangan status gizi ibu ketika hamil dan menyusui. Oleh karena itu, para ibu perlu dibekali pengetahuan yang baik tentang pentingnya ASI Eksklusif dan perlu dukungan dari berbagai pihak seperti keluarga, tenaga medis, tempat melahirkan, lingkungan maupun pemerintah.

Kandungan gizi yang terdapat dalam ASI sangat tinggi, diantanya kolostrum kaya antibodi dan mengandung protein yang diperlukan untuk daya tahan tubuh. Dengan demikian pemberian ASI Eksklusif pada bayi dapat menekan risiko kematian. Kolostrum dihasilkan pada hari pertama sampai ke-3 sesudah persalinan yang secara fisik berwarna kekuningan. Berikutnya hari ke-4 sampai hari ke-10, ASI mengandung immunoglobulin yang kaya dengan lemak dan kalori dan warna susu lebih putih. Selain itu, ASI juga mengandung enzim zat penyerap. Seorang ibu yang menyusui sejak dini akan berdampak positif baik untuk bayi maupun ibu. Bayi akan mendapatkan kehangatan ketika menyusu yang akan menurunkan resiko kematian akibat kedinginan (hypothemia). Ibu yang menyusui dapat mengurangi resiko morbiditas maupun mortalitas, karena menyusui akan merangsang kontraksi uterus sehingga mengurangi pendarahan setelah melahirkan. (Kementerian Kesehatan RI, 2018).

Pada laman Kementerian Kesehatan RI (www.kemenkes.go.id), disebutkan bahwa ASI marupakan makanan paling baik untuk bayi, terutama pada umur 0-6 bulan. Makanan/minuman 
Journal of Healthcare Technology and Medicine Vol. 6 No. 2 Oktober 2020

Universitas Ubudiyah Indonesia

e-ISSN : 2615-109X

jenis apapun tidak dapat menggantikan fungsinya. Bayi yang memperoleh ASI Eksklusif akan mendapatkan manfaat sangat besar. Mereka akan mengalami pertumbuhan dan perkembangan yang optimal dan tidak gampang sakit. Lebih lanjut dinyatakan bahwa, angka kematian bayi merupakan salah satu indikator kesehatan yang sangat penting untuk mengukur derajat kesehatan dan kemajuan suatu bangsa. ASI merupakan makanan terbaik yang dapat menekan angka kematian bayi. Pemberian ASI Eksklusif selama periode 6 bulan dapat mengurangi angka kematian balita sampai 13 persen.

Pemerintah Indonesia menaruh perhatian yang cukup tinggi, karena begitu pentingnya pemberian ASI Eksklusif bagi pertumbuhan dan perkembangan bayi. Pada tahun 2012 telah dikeluarkan Peraturan Pemerintah (PP) No. 33 tentang Pemberian Air Susu Ibu Eksklusif. PP tersebut menyatakan bahwa ASI Eksklusif adalah ASI yang diberikan kepada Bayi sejak dilahirkan selama 6 (enam) bulan, tanpa menambahkan dan/atau mengganti dengan makanan atau minuman lain. Disebutkan juga bahwa setiap ibu yang melahirkan harus memberikan ASI Eksklusif kepada bayi yang dilahirkannya, terkecuali ada hambatan yang dibenarkan. Tujuannya adalah untuk menjamin pemenuhan hak bayi agar mendapatkan ASI Eksklusif sejak dilahirkan sampai dengan berusia 6 bulan. Agar program pemberian ASI Eksklusif dapat berhasil diperlukan dukungan seluruh elemen baik pemerintah, swasta, maupun masyarakat.

Penelitian tentang ASI Eksklusif telah banyak dilakukan. Diantaranya dilakukan oleh Solikhati dkk (2018) yang meneliti hubungan antara pemberian ASI Eksklusif dengan pengetahuan ibu, pekerjaan ibu, dukungan keluarga dan dukungan tenaga kesehatan. Dalam penelitian tersebut dikatakan bahwa ASI Eksklusif adalah pemberian ASI tanpa makanan atau minuman tambahan selama enam bulan sejak pertama kelahiran terhadap bayi berusia 0 hingga 6 bulan. Beberapa hambatan dalam pemberian ASI Eksklusif diantaraya adalah pengetahuan ibu yang rendah, dukungan petugas kesehatan masih kurang, dan ibu yang bekerja. Lestari (2018) mengkaji faktor yang berpengaruh terhadap pemberian ASI Eksklusif di Desa Petapahan Kabupaten Kampar Provinsi Riau. Tujuannya adalah untuk mengetahui variabel apa saja yang berhubungan dengan pemberian ASI Eksklusif. Adapun variabel yang diteliti antara lain adalah pendidikan/pengetahuan ibu, pekerjaan ibu, umur dan dukungan petugas kesehatan.

Selanjutnya menurut Septiani dkk (2017) dalam penelitiannya di Bandar Lampung menyimpulkan bahwa variabel yang berhubungan dengan pemberian ASI Eksklusif adalah pengetahuan ibu dan dukungan keluarga. Faktor pengetahuan sangat penting dan dominan dalam meningkatkan pemberian ASI Eksklusif kepada bayi. Lebih lanjut disampaikan beberapa 
Journal of Healthcare Technology and Medicine Vol. 6 No. 2 Oktober 2020

Universitas Ubudiyah Indonesia

e-ISSN : 2615-109X

penyebab rendahnya pemberian ASI, diantaranya karena pengetahuan yang kurang dari ibu hamil, keluarga dan masyarakat. Selain itu juga dikarenakan kurangnya dukungan tempat bekerja dalam memberikan fasilitas ruang khusus laktasi.

Husna dkk (2019) melakukan penelitian di wilayah kerja Puskesmas Baiturrahman Banda Aceh. Mereka mengatakan bahwa pengetahuan seorang ibu tentang ASI Eksklusif yang kurang memadai dapat mempengaruhi atau menyebabkan kurang optimalnya pemberian ASI Eksklusif. Selain itu, dukungan suami terhadap istri dalam pemberian ASI Eksklusif kepada bayi sangat diperlukan. Sedangkan Afriyani dkk (2018) dalam penelitiannya di BPM Maimunah Palembang menyimpulkan bahwa faktor-faktor yang berhubungan dengan pemberian ASI Eksklusif adalah pekerjaan, usia, pendidikan dan jumlah anak (paritas). Menurut Afriani dkk sebagian besar ibu yang memberikan ASI Eksklusif pada bayinya adalah mereka yang berusia muda (20-30 tahun), tidak bekerja, berpendidikan tinggi, dan memiliki anak 2 orang atau lebih.

Menurut Ningsih (2018) dalam penelitiannya yang berjudul "Faktor-Faktor yang Mempengaruhi Pemberian ASI Eksklusif", menyatakan bahwa kecenderungan sebagian ibu tidak memberikan ASI Eksklusif kepada bayinya semakin besar. Berdasarkan data hasil penelitiannya, semakin banyak ibu yang memberikan makanan pendamping ASI sebelum waktunya. Faktorfaktor yang menjadi fokus penelitian Ningsih terkait pemberian ASI Eksklusif diantaranya adalah usia, paritas, pendidikan, pekerjaan, dukungan petugas kesehatan, dukungan keluarga, tempat bersalin.

Begitu besar dan pentingnya peranan ASI bagi pertumbuhan dan perkembangan bayi, namun capaian pemberian ASI Eksklusif di Provinsi Aceh masih relatif rendah. Berdasarkan data Badan Pusat Statistik (BPS) menunjukan bahwa pada tahun 2018 bayi dengan usia kurang dari enam (6) bulan yang mendapatkan ASI Eksklusif sebesar 44,36 persen, sedangkan untuk Provinsi Aceh sebesar 33,33 persen. Sementara target global dari dari Majlis Kesehatan Dunia (World Health Assembly/WHA) yaitu meningkatkan pemberian ASI Eksklusif untuk bayi berumur sampai 6 bulan minimal mencapai 50 persen pada tahun 2025. Capaian provinsi Aceh masih jauh dari target WHA.

Berdasarkan uraian tersebut di atas, penulis tertarik untuk meneliti dan mengidentifikasi karakteristik ibu menyusui dan variabel yang berhubungan dengan pemberian ASI Eksklusif. Kajian dan penelitian terkait pemberian ASI Eksklusif telah banyak dilakukan, akan tetapi sebagian besar merupakan studi kasus di tingkat desa atau kecamatan dengan sampel yang relatif kecil. Beberapa studi kasus dilakukan di wilayah kerja rumah sakit/rumah bersalin dan puskesmas. 
Journal of Healthcare Technology and Medicine Vol. 6 No. 2 Oktober 2020

Universitas Ubudiyah Indonesia

e-ISSN : 2615-109X

Penelitian terkait hubungan antara pemberian ASI eksklusif dengan tempat melahirkan/persalinan yang lebih rinci juga masih relatif sedikit. Pada penelitian ini, penulis menggunakan sampel relatif lebih besar yang tersebar di wilayah Provinsi Aceh, yaitu data hasil Survei Sosial Ekonomi Nasional (Susenas) yang dilaksanakan BPS. Hal ini penting, karena indikator yang digunakan sebagai bahan evaluasi capaian kinerja adalah berdasarkan indikator makro, dimana sebagiannya adalah dari hasil survei BPS.

\section{METODE PENELITIAN}

Penelitian ini menggunakan alat analisis deskriptif tabulasi silang dan uji chi square. Uji chi square adalah suatu alat uji statistik yang digunakan untuk mengetahui hubungan antara dua variabel. Menurut Irwan Gani dan Siti Amalia (2015) data yang digunakan untuk uji chi square adalah data yang berbentuk ordinal atau nominal dan jumlah sampelnya besar. Jika data yang digunakan berupa interval atau rasio, harus ditransformasi dulu ke dalam bentuk ordinal. Misalnya data rasio tentang jumlah pendapatan, harus dtransformasi menjadi pendapatan tinggi, pendapatan sedang, dan pendapatan rendah. Uji ini umumnya digunakan untuk menunjukkan kecenderungan secara deskriptif, dan untuk menguji hipotesis komparatif. Kecenderungan deskriptif adalah dugaan terhadap irama nilai satu populasi jika dikaitkan dengan beberapa sampel populasi secara berpasangan. Misalnya "Semakin kaya seseorang maka akan semakin tinggi tingkat konsumsinya”. Sedangkan hipotesis komparatif adalah dugaan terhadap perbandingan nilai dua populasi atau lebih yang diuji berdasarkan ukuran uji tertentu, dalam hal ini uji chi square. Misalnya "Terdapat hubungan yang signifikan antara tingkat kesejahteraan dengan tingkat pendidikan".

Data yang digunakan dalam penelitian ini adalah data hasil Survei Sosial Ekonomi Nasional (Susenas) Maret 2019 Provinsi Aceh yang dilaksanakan BPS. Unit penelitian adalah ibu yang memiliki anak berumur 6 - 23 bulan. Dari sampel Susenas tersebut diperoleh 1.403 ibu yang tersebar di seluruh wilayah Aceh. Penelitian ini difokuskan pada hubungan antara pemberian ASI Eksklusif kepada bayi hingga 6 bulan dengan beberapa karakteristik (variabel) ibu kandungnya, yaitu pendidikan, status bekerja, umur, , dan tempat melahirkan.

\section{HASIL DAN PEMBAHSAN}

Tabel 1. Karakteristik Sampel 


\begin{tabular}{|c|c|c|c|}
\hline & \multirow{2}{*}{ Uraian } & \multicolumn{2}{|c|}{ Total } \\
\hline & & Jumlah & $\%$ \\
\hline \multirow{4}{*}{ Tingkat Pendidikan } & SD ke bawah & 250 & 17.82 \\
\hline & SMP & 321 & 22.88 \\
\hline & SMA & 475 & 33.86 \\
\hline & D1 ke atas & 357 & 25.44 \\
\hline \multirow{2}{*}{ Status Bekerja } & Bekerja & 400 & 28.51 \\
\hline & Tidak & 1.003 & 71.49 \\
\hline \multirow{5}{*}{ Umur (Tahun) } & 24 th kebawah & 201 & 14.33 \\
\hline & $25-29$ & 403 & 28.72 \\
\hline & $30-34$ & 414 & 29.51 \\
\hline & $35-39$ & 282 & 20.10 \\
\hline & 40 ke atas & 103 & 7.34 \\
\hline \multirow{7}{*}{ Tempat melahirkan } & RS Pemerintah/Swasta/IA & 506 & 36.07 \\
\hline & Rumah Bersalin & 290 & 20.67 \\
\hline & Puskesmas/Pustu & 160 & 11.40 \\
\hline & Praktek Nakes & 123 & 8.77 \\
\hline & Polindes/Poskesdes & 141 & 10.05 \\
\hline & Rumah & 183 & 13.04 \\
\hline & Total & 1.403 & 100,00 \\
\hline
\end{tabular}

Tabel 1 di atas menyajikan karakteristik ibu yang mempunyai bayi berumur 6-23 bulan. Dari total sampel berjumlah $1.403 \mathrm{ibu}$, sebagian besar berpendidikan SMA ke atas yaitu sebesar 59,30 persen. Hal tersebut mengindikasikan bahwa tingkat pendidikan ibu yang lebih tinggi diharapkan mampu mendidikan anak dengan baik sejak bayi, sehingga anak yang merupakan aset bangsa dapat tumbuh dan berkembang dengan gizi yang baik. Selanjutnya status bekerja ibu. Pada era sekarang ini perempuan yang sudah mengecap pendidikan lebih tinggi, dapat bekerja mencari nafkah untuk membantu beban ekonomi keluarga. Bukan suatu hal yang tabu jika perempuan bekerja pada posisi yang tinggi, walaupun kondisi saat ini masih didominasi oleh laki-laki. Beberapa tantangan harus dihadapi jika seorang ibu bekerja sementara juga harus mengurus rumah tangga. Tabel 1 memperlihatkan bahwa ibu yang memiliki anak usia 6 - 23 bulan sebesar 28,48 persen dari mereka adalah bekerja.

Jika ditinjau dari usia, sebagian besar ibu yang menjadi sampel penelitian ini berusia 25 29 tahun (28,72 persen) dan 30 - 34 tahun (29,51 persen). Sedangkan yang berumur 40 tahun ke atas hanya 7,34 persen. Secara biologis, semakin bertambah usia seorang perempuan akan semakin turun kualitas dan kuantitas sel telur dan menurunkan tingkat kesuburan. Dengan demikian, semakin tua usia perempuan akan menurunkan kemungkinan kehamilan dan punya anak lagi. 
Fasilitas dan sarana kesehatan merupakan salah satu faktor pendukung penting dalam meningkatkan pelayanan kesehatan kepada masyarakat, termasuk sebagai tempat melahirkan. Semakin baik fasilitas dan pelayanan kesehatan sebagai tempat melahirkan, akan mengurangi risiko komplikasi persalinan dan risiko kemtian ibu, karena ibu akan memperoleh standar perawatan persalinan dengan peralatan dan tenaga kesehatan yang memadai. Fasilitas kesehatan yang dimaksud di sini adalah rumah sakit, rumah bersalin/klinik, puskesmas/pustu, praktek tenga kesehatan, dan polindes/poskesdes. Pada Tabel 1 memperlihatkan kondisi yang cukup baik, dimana sebagian besar ibu melahirkan di rumah sakit sebesar 36,07 persen dan di rumah bersalin 20,67 persen, akan tetapi masih ada ibu yang melahirkan di rumah walaupun relatif sedikit yaitu 13,04 persen.

\section{Hubungan Tingkat Pendidikan Ibu dengan Pemberian ASI Eksklusif}

Pada Tabel 2 terlihat bahwa Ibu dengan tingkat pendidikan D1 ke atas yang menyusui bayinya dengan ASI Eksklusif sebesar 60,78 persen, persentase ini tertinggi dibanding yang lain. Sedangkan persentase ibu yang memberikan ASI Eksklusif kepada bayinya terendah dengan tingkat pendidikan SMP yaitu sebesar 45,79 persen.

Selanjutnya, berdasarkan uji statistik chi square menggunakan SPSS dihasilkan nilai PValue $=0,001$, artinya terdapat hubungan antara tingkat pendidikan ibu dengan pemberian ASI Eksklusif. Semakin tinggi tingkat pendidikan ibu maka akan semakin baik pemberian ASI Eksklusifi. Hasil ini sejalan dengan penelitian yang dilakukan Widiyanto dkk (2012) di Desa Keramat Kecamatan Penawangan Kabupaten Grobogan, yaitu ada hubungan posistif yang signifikan antara pendidikan ibu dengan pemberian ASI Eksklusif. Demikian juga hasil penelitian dari Mestika Lumbantoruan (2018) menyatakan terdapat hubungan antara pendidikan ibu dengan ASI Eksklusif. Lumbantoruan menyatakan bahwa masih banyak ibu tidak memberikan ASI Eksklusif karena pendidikan mereka yang rendah.

Tabel 2. Pemberian ASI Eksklusif Menurut Tingkat Pendidikan Ibu

\begin{tabular}{cccccccc}
\hline \multirow{2}{*}{$\begin{array}{c}\text { Tingkat Pendidikan } \\
\text { Ibu }\end{array}$} & \multicolumn{9}{c}{ Pemberian ASI Eksklusif } & \multirow{2}{*}{ Total } & $\%$ & \multirow{2}{*}{ P-Value } \\
\cline { 2 - 6 } & Ya & $\%$ & Tidak & $\%$ & & & \\
\hline SD ke bawah & 128 & 51,20 & 122 & 48,80 & 250 & 100,00 & \\
\hline SMP & 147 & 45,79 & 174 & 54,21 & 321 & 100,00 & \\
\hline SMA & 282 & 59,37 & 193 & 40,63 & 475 & 100,00 & 0,001 \\
\hline D1 Ke atas & 217 & 60,78 & 140 & 39,22 & 357 & 100,00 & \\
\hline Jumlah & 774 & 55,17 & 629 & 44,83 & 1.403 & 100,00 \\
\hline
\end{tabular}


Journal of Healthcare Technology and Medicine Vol. 6 No. 2 Oktober 2020

Universitas Ubudiyah Indonesia

e-ISSN : 2615-109X

\section{Hubungan Status Bekerja Ibu dengan Pemberian ASI Eksklusif}

Perempuan yang menajadi Ibu dan bekerja tentunya waktu yang diberikan untuk keluarga akan berkurang. Sehingga seorang ibu yang mempunyai bayi harus dapat mengatur waktu untuk menjalin hubungan emosional dengan bayinya, termasuk mengatur dalam pemberian ASI Eksklusif. Pada Tabel 3 memperlihatkan bahwa ibu yang bekerja, masih meluangkan waktu untuk memberikan ASI Eksklusif kepada bayinya sebesar 60,50 persen, mengingat sangat penting ASI eksklusif untuk pertumbuhan dan perkembangan bayi.

Berikutnya, hasil uji chi square menunjukkan nilai $\mathrm{P}$-Value $=0,011$, artinya terdapat hubungan antara status bekerja ibu dengan pemberian ASI Eksklusif. Hal ini sejalan dengan hasil penelitian di Desa Bangun Rejo Kecamatan Tanjung Morawa Medan oleh Mestika Lumbantoruan (2018), yang menyatakan bahwa ada hubungan yang signifikan antara ibu yang bekerja dengan pemberian ASI eksklusif. Ibu yang tidak bekerja cenderung lebih banyak memberikan ASI Eksklusif pada bayinya. Berbeda dengan hasil penelitian yang dilakukan Herlina Susmaneli (2013) di Wilayah Puskesmas Rambah Hilir I Kabupaten Rokan Hulu, yang menyatakan bahwa tidak ada hubungan yang signifikan antara pekerjaan ibu dengan ASI Eksklusif yang diberikan kepada bayinya. Perbedaan ini bisa saja disebabkan jumlah sampel dan lokasi penelitian.

Tabel 3. Pemberian ASI Eksklusif Menurut Status Bekerja Ibu

\begin{tabular}{cccccccc}
\hline \multirow{2}{*}{ Status Bekerja } & \multicolumn{4}{c}{ Pemberian ASI Eksklusif } & \multirow{2}{*}{ Total } & $\%$ & \multirow{2}{*}{$\begin{array}{c}\text { P- } \\
\text { Value }\end{array}$} \\
\cline { 2 - 5 } & Ya & $\%$ & Tidak & $\%$ & & & \% \\
\hline Bekerja & 242 & 60,50 & 158 & 39,50 & 400 & 100,00 & \multirow{2}{*}{0,011} \\
\hline Tidak Bekerja & 532 & 53,04 & 471 & 46,96 & 1003 & 100,00 & \\
\hline Jumlah & 774 & 55,17 & 629 & 44,83 & 1.403 & 100,00 & \\
\hline
\end{tabular}

\section{Hubungan Umur Ibu dengan Pemberian ASI Eksklusif}

Biasanya umur seseorang akan berpengaruh terhadap kondisi kebugaran dan ketahanan tubuh. Ibu yang lebih muda akan lebih kuat dan memiliki enerji yang lebih besar untuk mengurus rumah tangga dan begadang untuk bayinya. Secara umum terlihat bahwa menurut kelompok umur persentase ibu yang menyusui bayinya dengan ASI Eksklusif lebih dari separuhnya. Persentase tertinggi terdapat pada kelompok umur 40 tahun ke atas dan 30-34 tahun, masing-masing 58,25 persen dan 58,21 persen.

Selanjutnya, berdasarkan uji chi square didapatkan nilai P-Value $=0,472$, artinya tidak terdapat hubungan antara umur ibu dengan pemberian ASI Eksklusif. Hal ini sejalan dengan penelitian yang dilakukan oleh Simanungkalit (2018)yang melakukan penelitian ini di wilayah 
Journal of Healthcare Technology and Medicine Vol. 6 No. 2 Oktober 2020

Universitas Ubudiyah Indonesia

e-ISSN : 2615-109X

kerja Puskesmas Jekan Raya kota Palangka Raya. Berdasarkan hasil penelitiannya, Simanungkalit menyatakan bahwa hasil uji statistik menunjukkan tidak terdapat hubungan antara umur ibu dengan ASI eksklusif yang diberikan pada bayinya. Berbeda dengan hasil penelitian Afriyani dkk (2018) di BPM Maimunah Palembang, yang menyatakan bahwa terdapat hubungan antara umur ibu dengan pemberian ASI Eksklusif. Lebih lanjut Afriani menyatakan bahwa ibu yang berusia 20-30 tahun, akan lebih tinggi kecenderungan menyusui bayinya secara Eksklusif dibandingkan dengan ibu yang berumur di bawah 20 tahun atau di atas 30 tahun.

Tabel 4. Pemberian ASI Eksklusif Menurut Kelompok Umur Ibu

\begin{tabular}{|c|c|c|c|c|c|c|c|}
\hline \multirow{2}{*}{ Umur Ibu (Tahun) } & \multicolumn{4}{|c|}{ Pemberian ASI Eksklusif } & \multirow{2}{*}{ Total } & \multirow{2}{*}{$\%$} & \multirow{2}{*}{$\begin{array}{c}\text { P- } \\
\text { Value }\end{array}$} \\
\hline & $\mathrm{Ya}$ & $\%$ & Tidak & $\%$ & & & \\
\hline 24 ke bawah & 106 & 52,74 & 95 & 47,26 & 201 & 100,00 & \multirow{6}{*}{0,472} \\
\hline $25-29$ & 220 & 54,59 & 183 & 45,41 & 403 & 100,00 & \\
\hline $30-34$ & 241 & 58,21 & 173 & 41,79 & 414 & 100,00 & \\
\hline $35-39$ & 147 & 52,13 & 135 & 47,87 & 282 & 100,00 & \\
\hline $40 \mathrm{ke}$ atas & 60 & 58,25 & 43 & 41,75 & 103 & 100,00 & \\
\hline Jumlah & 774 & 55,17 & 629 & 44,83 & 1.403 & 100,00 & \\
\hline
\end{tabular}

\section{Hubungan Tempat Melahirkan dengan Pemberian ASI Eksklusif}

Setelah mengandung sekitar 9 bulan lamanya, kelahiran anak merupakan momen penting yang ditunggu dan didambakan oleh ibu dan keluarga. Agar proses persalinan berjalan lancar dan nyaman, perlu dukungan dari keluarga dan fasilitas tempat bersalin. Dukungan tersebut bukan hanya pada saat proses persalinan, tetapi juga pasca persalinan dan saat pemberian ASI Eksklusif kepada bayi. Tempat melahirkan diharapkan dapat memberikan dukungan kenyamanan dalam memberikan ASI Eksklusif kepada bayi yang baru dilahirkan. Pada Tabel 5 terlihat bahwa sebagian besar ibu (36,07 persen dari total sampel 1.403) melahirkan di rumah sakit (RS), baik RS Pemerintah, Swasta, maupun RS Ibu dan Anak. Kemudian ibu yang melahirkan di Rumah Bersalin sebesar 20,67 persen. Masih ada ibu yang melahirkan di rumah, walaupun jumlahnya relatif sedikit (13,04 persen).

Hasil uji chi square menunjukkan nilai P-Value $=0,030$, artinya terdapat hubungan antara tempat melahirkan denga pemberian ASI Eksklusif. Semakin baik tempat melahirkan, semakin baik pemberian ASI Eksklusif kepada bayi. Hasil ini tidak sejalan dengan penelitian yang dilakukan oleh Fakhidah dan Palupi (2018), yang menyatakan bahwa berdasarkan hasil uji statistik 
Journal of Healthcare Technology and Medicine Vol. 6 No. 2 Oktober 2020

Universitas Ubudiyah Indonesia

e-ISSN : 2615-109X

tidak ada hubungan yang signifikan antara pemberian ASI Eksklusif dengan tempat melahirkan. Dalam penelitian tersebut hanya membandingkan antara Rumah Sakit dengan Bidan Praktek Mandiri (BPM)/Pos Kesehatan Desa (PKD). Perbedaan ini dapat saja terjadi karena jumlah sampel yang relatif lebih sedikit dan variasi jenis tempat melahirkan yang juga lebih sedikit. Penelitian lain dilakukan oleh Asyifa Norhana dkk (2016), yang mengkaji hubungan antara tempat melahirkan dan penolong kelahiran dengan praktek inisiasi menyusui dini. Jenis tempat persalinan hanya dibagi dua yaitu melahirkan di fasilitas kesehatan dan non faslilitas kesehatan. Hasil penelitian tersebut menyatakan bahwa terdapat hubungan yang nyata antara tempat persalinan dengan pelaksanaan insiasi menyusu dini. Lebih lanjut Norhana manyatakan bahwa sebagian besar ibu yang tidak melakukan inisiasi menyusui dini, persalinannya dilakukan di bukan fasilitas kesehatan. Peluang ibu yang melahirkan bayinya di fasilitas kesehatan melakukan inisiasi dini menyusui jauh lebih besar dibandingkan dengan yang melahirkan di bukan fasilitas kesehatan.

Tabel 5. Pemberian ASI Eksklusif Menurut Tempat Melahirkan

\begin{tabular}{cccccccc}
\hline \multirow{2}{*}{ Tempat Melahirkan } & \multicolumn{3}{c}{ Pemberian ASI Eksklusif } & \multirow{2}{*}{ Total } & $\%$ & P-Value \\
\cline { 2 - 5 } $\begin{array}{c}\text { Ya } \\
\text { RS }\end{array}$ & Ya & Tidak & $\%$ & & \\
\hline Pemerintah/Swasta/RSIA & 274 & 54,15 & 232 & 45,85 & 506 & 100,00 \\
\hline Rumah Bersalin & 170 & 58,62 & 120 & 41,38 & 290 & 100,00 \\
\hline Puskesmas/Pustu & 92 & 57,50 & 68 & 42,50 & 160 & 100,00 & 0,030 \\
\hline Praktek Nakes & 52 & 42,28 & 71 & 57,72 & 123 & 100,00 & \\
\hline Polindes/Poskesdes & 88 & 62,41 & 53 & 37,59 & 141 & 100,00 \\
\hline Rumah & 98 & 53,55 & 85 & 46,45 & 183 & 100,00 \\
\hline Jumlah & 774 & 55,17 & 629 & 44,83 & 1.403 & 100,00 \\
\hline
\end{tabular}

\section{KESIMPULAN}

Secara umum jumlah ibu yang memberikan ASI Eksklusif kepada bayinya lebih besar yaitu 55,17 persen, sedangkan ibu yang tidak memberikan ASI Eksklusif kepada bayinya sebesar 44,83 persen. Penelitian ini juga menelaah hubungan antara pemberian ASI Eksklusif dengan beberapa variabel. Berdasarkan hasil pengujian chi square dengan taraf signifikan $\alpha=0,05$, beberapa variabel terbukti secara nyata mempunyai hubungan dengan pemberian ASI Eksklusif. Variabel tersebut adalah tingkat pendidikan ibu, status bekerja ibu, dan tempat melahirkan. 
Journal of Healthcare Technology and Medicine Vol. 6 No. 2 Oktober 2020

Universitas Ubudiyah Indonesia

e-ISSN : 2615-109X

Sedangkan variabel umur tidak terdapat hubungan yang signifikan dengan pemberian ASI Eksklusif.

Hasil temuan tersebut diharapkan dapat bermanfaat bagi masyarakat dan bangsa ini. Persiapan ibu sebelum melahirkan dan dukungan semua pihak sangat penting dalam mensukseskan pemberian ASI Eksklusif. Dengan memberi ASI Eksklusif berarti telah mempersiapkan SDM unggul sejak dini untuk kemajuan bangsa di masa depan.

\section{DAFTAR PUSTAKA}

Afriyani, R., Savitri, I., \& Sa'adah, N. (2018). Pengaruh Pemberian ASI Eksklusif di BPM Maimunah Palembang. Jurnal Kesehatan, 9(2), 330-334.

Fakhidah, L. N., \& Palupi, F. H. (2018). Analisis Faktor yang Mempengaruhi Pemberian ASI Eksklusif. Jurnal Kebidanan. X(02), 181-192.

Husna, A., Safitri, F., \& Rahmi, N. (2019). Faktor-Faktor yang Berhubungan dengan Pemberian ASI Eksklusif di Wilayah Kerja Puskesmas Baiturrahman. Journal of Healthcare Technology and Medicine. 5(1), 140-147.

Irwan Gani dan Siti Amalia. (2015). Alat Analisis Data: Aplikasi Statistik untuk Penelitian Bidang Ekonomi dan Sosial (Revisi). Andi.

Kementerian Kesehatan RI. (2018). Profil Kesehatan Indonesia.

Lestari, R. R. (2018). Faktor-Faktor yang Berhubungan dengan Pemberian ASI Ekslusif pada Ibu. Jurnal Obsesi: Jurnal Pendidikan Anak Usia Dini. 2(1), 131-136.

Lumbantoruan, M. (2018). Hubungan Karakteristik Ibu Menyusui dengan Pemberian ASI Eksklusif pada Bayi di Desa Bangun Rejo Kecamatan Tanjung Morawa. Jurnal Maternal dan Neonatal. 3(1), 13-22.

Ningsih, D. A. (2018). Faktor-Faktor yang Mempengaruhi Pemberian ASI Eksklusif. Jurnal Penelitian Kesehatan Suara Forikes.. 9(April), 101-113.

Norhana, Asyifa, S. Arifin. dan F. Yulidasari. (2016). Hubungan Tempat Persalinan dan Jenis Penolong Persalinan dengan Pelaksanaan Inisiasi Menyusu Dini di Puskesmas Martapura. Jurnal Publikasi Kesehatan Masyarakat Indonesia 3(2) , 51-58.

Septiani, Hanulan, Artha Budi, \& Karbitos (2017). Faktor-Faktor yang Berhubungan dengan Pemberian ASI Eksklusif Oleh Ibu Menyusui yang Bekerja Sebagai Tenaga Kesehatan. Jurnal Ilmu Kesehatan: Aisyah. 2(2), 159-174.

Simanungkalit, H. M. (2018). Status Pekerjaan Dan Pengetahuan Ibu Menyusui Terhadap 
Journal of Healthcare Technology and Medicine Vol. 6 No. 2 Oktober 2020

Universitas Ubudiyah Indonesia

e-ISSN : 2615-109X

Pemberian ASI Eksklusif. Jurnal Info Kesehatan. 16(2), 236-244.

Solikhati, F., Sukowati, F., \& Sumarni, S. (2018). Analisis Faktor yang Berhubungan dengan Pemberian ASI Eksklusif pada Bayi 0-6 Bulan di Kecamatan Wonotunggal. Jurnal Kebidanan. 7(15), 62-74.

Susmaneli, H. (2013). Faktor-Faktor yang Berhubungan dengan Pemberian ASI Eksklusif di Wilayah Kerja Puskesmas Rambah Hilir I Kabupaten Rokan Hulu. Jurnal Kesehatan Komunitas. 2(2), 67-71.

Widiyanto, S., Aviyanti, D., \& A, Merrry T. (2012). Hubungan Pendidikan dan Pengetahuan Ibu tentang ASI Eksklusif dengan Sikap terhadap Pemberian ASI Eksklusif. Jurnal Kedokteran Muhammadiyah. 1(2), 25-29.

World Health Organization. (2020). Breastfeeding and COVID-19. Scientific Brief. June. 